\title{
Genetic Analysis of Flower Bud Thrips Resistance (Megalurothrips sjostedti) in Cowpea (Vigna unguiculata [L.] Walp.) in Burkina Faso
}

\author{
Hamadou Sidibe, PhD Student \\ University Joseph KI-ZERBO, Ouagadougou, Burkina Faso, Institute of \\ Environment and Agricultural Research (INERA), Ouaga, Burkina Faso \\ Benoit Joseph Batieno, PhD \\ Institute of Environment and Agricultural Research (INERA), \\ Ouaga, Burkina Faso \\ Tinga Jeremy Ouedraogo, PhD
}

African Union Development Agency (AUDA-NEPAD), Dakar ,Senegal

Jean-Baptiste Tignegre, PhD

World Vegetable Centre (AVRDC), Bamako, Mali

Mahamadou Sawadogo, PhD

Genetic and Plant Breeding, University Joseph KI-ZERBO,

Ouagadougou, Burkina Faso

Doi: 10.19044/esj.2019.v15n18p23～URL:http://dx.doi.org/10.19044/esj.2019.v15n18p23

\begin{abstract}
Cowpea is an important grain legume in sub Saharan Africa where its protein rich grains are consumed. However, its production is hampered by some major constraints including flower bud thrips (Megalurothrips sjostedti) that can cause $60 \%$ to total crop yield loss. Therefore, the development of resistant varieties becomes necessary. Thus, the present study was designed to determine the inheritance and elucidate the genetic control of cowpea resistance to thrips. Generation mean analysis model was exploited to assess the mode of inheritance of the resistance to flower bud thrips in cowpea using six generations (P1, P2, F1, F2, BC1P1 and BC1P2) derived from cross of Komcallé and Sanzi. Parameters such as number of flowers abortion per plant, number of pods per plant, thrips damage, number of thrips per plant and 100 seeds weight were exploited for progenies evaluation. Generation mean analysis revealed the existence of additive (a), additive $x$ dominance ( $\mathrm{ad}$ ) and dominance $\mathrm{x}$ dominance ( $\mathrm{dd}$ ) effects as the mode of gene action predominantly involved into cowpea for thrips resistance control. Number of effective factors for thrips damage control varied from 3 (number of aborted flowers per plant) to 6 (weight of 100 seeds). Estimated Broad and
\end{abstract}


narrow sense heritabilities for flower bud thrips resistance were low indicating large effect of the environment on the trait.

Keywords: Cowpea, generation mean analysis, Thrips, gene effects

\section{Introduction}

Cowpea, Vigna unguiculata (L.) Walp., (Fabaceae) is a major source of cheap plant protein. Total yield loss has been reported from insects (Singh and Allen, 1980). One of the major pests of cowpea in tropical Africa is the flower thrips, Megalurothrips sjostedti (Trybom). The search for resistant varieties will be a good solution to solve this statement. The use of cowpea cultivars resistant to thrips is among the most promising control measures (Agbahoungba et al., 2018). Cowpea landrace, Sanzi from Ghana, was identified with a high level of resistance to flower thrips in Nigeria, Mali, Cameroon, Kenya and Burkina Faso (Ngakou et al., 2008; Omo-Ikerodah et al., 2009; Dormatey et al., 2015;Gonné et al,2018; Sidibé et al., 2018; Doumbia et al., 2019). It would therefore be a promising donor for thrips resistance transfer. In genetic analysis of cowpea resistance to flower thrips in Nigeria, Omo-Ikerodah et al. (2009) reported more than two genes probably controlling the resistance to flower thrips in addition to additive $x$ additive and dominance $x$ dominance as mode of gene effects for resistance to Megalurothrips sjostedti. Domartey et al. (2015) and Gonné et al. (2018) reported additive, dominance and their interaction effects making major contributions for cowpea resistance to thrips in Ghana and Cameroun, respectively. The question of the mode of inheritance has been approached as Cameroon, however we may not have the same biotype that is facing West Africa, particular in Burkina Faso. Thrips are susceptible to environmental changes because of the polyphagous nature of many species, one can determine their abundance by the types of plant formations. Moreover, the insects have sometimes specific environment and different biotypes. Cameroon and Nigeria ecologies are different from Burkina Faso and information related on mode of gene action governing the inheritance of resistant of cowpea to flower bud thrips damage is not available in Burkina Faso. It is therefore necessary to understand the mode of inheritance of cowpea resistance to thrips in Burkina Faso. Genetic analysis using generation mean analysis (GMA) has been used to estimate the gene actions controlling the quantitative characters. Determining these components will contribute to a better understanding of gene action involved in the expression of these characters (Prabhu, 2017). The concept of generation mean analysis was given by Hayman (1958), Jinks and Jones (1958). Procedure for generation mean analysis is development of Basic Generations, recording from observations and testing of a model. Generation mean analysis or scaling 
tests have been widely used for genetic analysis and can provide information on nature and magnitude of the gene (s) involved in this mechanism of resistance to flower bud thrips (Megalurothrips sjostedti) in cowpea (Vigna unguiculata [L.] Walp.). Therefore, the objective of this study was to elucidate the mode of inheritance of genes controlling the resistance of cowpea to flower bud thrips among the resistance sources in order to set up a breeding program of cowpea for integrated pest management in Burkina Faso.

\section{Materials and Methods \\ Experimental material}

The experimental material consisted of six generations composed of parent $1(\mathrm{P} 1)$, parent $2(\mathrm{P} 2), \mathrm{F}_{1}, \mathrm{~F}_{2}, \mathrm{BC}_{1} \mathrm{P} 1$ and $\mathrm{BC}_{1} \mathrm{P} 2$ derived from crossing between Komcallé (P1) and Sanzi (P2). Sanzi is a landrace from Ghana that was identified resistant to thrips (Megalurothrips sjostedti) during the screening. It is an extra early variety with maturity occurring from 55 to 60 days, erect habit and very small seeds' size. Komcallé is an improved variety developed and released by Institute of Environment and Agricultural Research (INERA) and very susceptible to thrips (Megaluropthrips sjostedti). It is an early maturing variety with 60 days, semi-prostrate habit and white seeds.

Thrips used in this study were reared in the laboratory, $\mathrm{KN}-1$ varieties and pigeon pea were planted on fields at different sowing dates to ensure continuous flower production and quickly build up thrips population. These fields were used as sources of inoculum of thrips. The peduncles were cut into small pieces and sprinkled with a little amount of water on a tissue paper. Bundle of peduncles were wrapped in the damp of tissue paper, their base were covered with the tissue. Brown paper was cut and folded in diagonally to make a pouch which ends were secured with a tape. Peduncle bunch were put into pouch. Sampled flowers were poured on laboratory bench and their petals were gently teased out to release thrips. Aspirator was used to collect thrips and placed them into pouch containing the peduncles. Maximum thrips was sampled for different pouch and covered them with a masking tape. Sealed pouch were placed into a plastic container, covered with a white cotton cloth and secure with a plastic band and left them under room temperature. Peduncles were renewed after every 48 hours with new ones and infested with more thrips if needed.

\section{Experimental design and data collection}

Randomized complete block design (RCBD) with three replications was used to screen cowpea samples. Each replication was constituted of 150 pots which were filled with a mixture of sand and topsoil. Each line was represented by a pot corresponding to the experimental unit. Two to three 
seeds were initially planted in the pots and thinned to one plant per pot after emergence. Sample 40 thrips into a vial and plug the opening of the vial with cotton to prevent the thrips from escaping. The vial was placed on an ice pack or inside the fridge for approximately 3-5 minutes to knockdown the thrips and facilitate their handling during infestation.

Each plant was infested with 40 thrips at flower bud initiation or from the appearance of the first flower by placing them on the lower leaves or near or on the flower buds. Infested cowpea plants were covered with an insectproof sleeve cage to prevent thrips escaping and also ensure no further external environmental influence.

\section{Data collection}

Data were scored from 30 individual plants from non-segregating populations ( $\mathrm{F}_{1}$ and their parents), 120 individual backcross plants $\left(\mathrm{BC}_{1} \mathrm{P} 1\right.$ and $\mathrm{BC}_{1} \mathrm{P} 2$ ) and 120 plants for each of the $\mathrm{F}_{2}$ generations. Thrips damages were recorded base on the scale described previously by Jackai and Singh (1988) adapted by Sidibé et al. (2018).

\section{Plant damage:}

- The number of pods per plant;

- The number of aborted flowers per plant;

- The number of thrips per plant; and

- 100 seed weight.

Flower damage scoring:

1. No browning/drying of flowers (resistant insect);

2. Initiation of browning of the flowers (highly tolerant);

3. Distinct browning/drying of flowers (tolerant);

4. Serious browning/drying of flowers (susceptible); and

5. Heavy browning/drying of flowers (highly susceptible). 


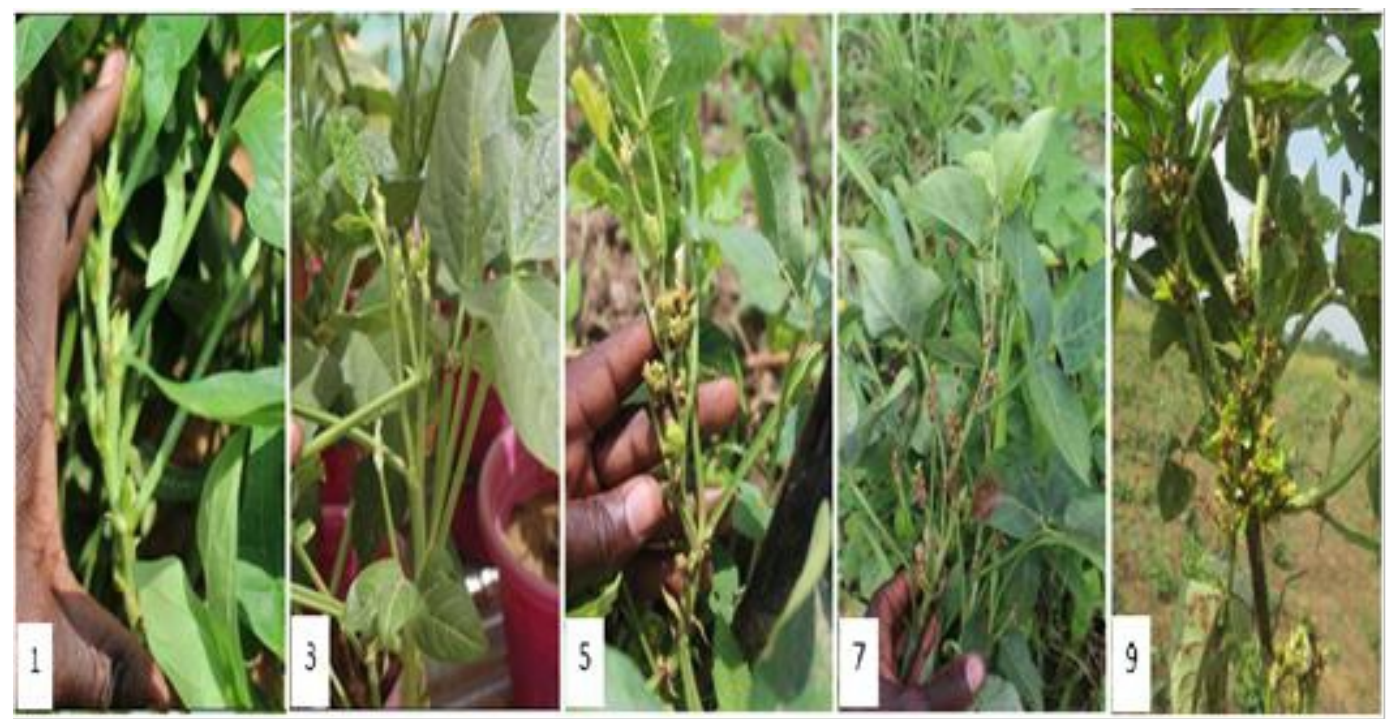

Figure 1: Adapted scale used for scoring M. sjostedti damage (Sidibé et al., 2018)

\section{Data analyses}

Data collected were subjected to Analysis of variance to check the difference among the generations using XLSTAT statistical software (Addinsoft, 2019) and data analysis solution Long Island, NY, USA. Generation mean analysis (GMA) was performed on Plant Breeding Tools software to determine the types of gene action controlling the inheritance of resistance of flower bud thrips in cowpea using thrips damage scores and number of thrips per flower. The generation mean analysis (GMA) was used to measure genetic parameters following the procedure described by Kang (1994). Generation mean was calculated for six generations on an individual plant basis. Mather (1949) and Hayman (1955) methods were exploited to test the adequacy of the additive-dominance model using $\mathrm{A}, \mathrm{B}, \mathrm{C}$ and $\mathrm{D}$ scaling test. If the values of $\mathrm{A}, \mathrm{B}, \mathrm{C}$ and $\mathrm{D}$ become zero (0), additive-dominance model is adequate. But if the value is significantly different from zero (0), it means epistasis genes are present and additive-dominance model is not adequate. Scaling test A, B, C and D scales, their variances, standard errors and ' $\mathrm{t}$ ' test were calculated using the following formulae:

$$
\begin{aligned}
& \mathrm{A}=2 * \mathrm{BC} 1 \mathrm{P} 1-\mathrm{P} 1-\mathrm{F} 1 \\
& \mathrm{~B}=2 * \mathrm{BC} 1 \mathrm{P} 2-\mathrm{P} 2-\mathrm{F} 1 \\
& \mathrm{C}=4 * \mathrm{~F} 2-2 * \mathrm{~F} 1-\mathrm{P} 1-\mathrm{P} 2 \\
& \mathrm{D}=2 \mathrm{~F} 2-\mathrm{BC} 1-\mathrm{BC} 2
\end{aligned}
$$

Where, P1, P2, F1, F2, B1 and B2 are the six generations from replications. 
The variances of these tests were calculated as follows:

$\mathrm{VA}=4 \mathrm{VBC} 1+\mathrm{VP} 1+\mathrm{VF} 1$

$\mathrm{VB}=4 \mathrm{VBC} 2+\mathrm{VP} 2+\mathrm{VF} 1$

$\mathrm{VC}=16 \mathrm{VF} 2+4 \mathrm{VF} 1+\mathrm{VP} 1+\mathrm{VP} 2$

$\mathrm{VD}=4 \mathrm{VF} 2+\mathrm{VBC} 1+\mathrm{BC} 2$

The significance of test deviations from zero was tested using their standard errors:

$\mathrm{SEA}=\sqrt{\mathrm{VA}}$

$\mathrm{SEB}=\sqrt{ } \mathrm{VB}$

$\mathrm{SEC}=\sqrt{ } \mathrm{V} \mathrm{C}$

$\mathrm{SED}=\sqrt{ } \mathrm{V} \mathrm{D}$

The variances (VA, VB, VC and VD) of the scales A, B, C and D were obtained as the square root of VA, VB, VC and VD, respectively. The significance of the deviations of the scales from zero was tested using their standard errors.

The student test:

$\mathrm{T}_{\mathrm{A}}=\mathrm{A} / \mathrm{SEA}$

$\mathrm{T}_{\mathrm{B}}=\mathrm{B} / \mathrm{SEB}$

$\mathrm{T}_{\mathrm{C}}=\mathrm{C} / \mathrm{SEC}$

$\mathrm{T}_{\mathrm{D}}=\mathrm{D} / \mathrm{SED}$

The significance of the scales A, B, C and D was determined by comparing the observed and expected ' $\mathrm{t}$ ' values at 5 and $1 \%$ level of significance. When any one of the four scales was found to deviate significantly from zero, the additive - dominance model was considered inadequate. In such case, the joint scale test was employed (Cavalli, 1952). The main drawbacks of the scaling tests are out of the six populations only three or four are included at a time. It does not provide estimates of $\mathrm{m}$ [d], [h]. It does not test goodness of fit of a model. Cavalli (1952) devised a method known as Joint scaling test to overcome these limitations.

The mode of inheritance of thrips resistance was estimated for each cross by generation mean analysis (P1, P2, F1, BC1P1, F2 and BC1P2) based on additive/dominance model and three parameter model (Mather and Jinks, 1982). Gene effects were estimated as:

$\mathrm{m}=1 / 2 \mathrm{P} 1+1 / 2 \mathrm{P} 2+4 \mathrm{~F} 2-2 \mathrm{BC} 1 \mathrm{P} 1-2 \mathrm{BC} 1 \mathrm{P} 2$

$\mathrm{a}=1 / 2 \mathrm{P} 1-1 / 2 \mathrm{P} 2$

$\mathrm{SE}(\mathrm{a})=0.5 / 2 \mathrm{SE} \mathrm{P} 1+0.5 / 2 \mathrm{SE} \mathrm{P} 2$ 
$\mathrm{d}=6 \mathrm{BC} 1 \mathrm{P} 1+6 \mathrm{BC} 1 \mathrm{P} 2-8 \mathrm{~F} 2-\mathrm{F} 1-3 / 2 \mathrm{P} 1-3 / 2 \mathrm{P} 2$

$\mathrm{SE}(\mathrm{d})=36 \mathrm{SE} \mathrm{BC} 1 \mathrm{P} 1+36 \mathrm{SE} \mathrm{BC} 1 \mathrm{P} 2+64 \mathrm{SE} \mathrm{F} 2+\mathrm{SE} \mathrm{F} 1+9 / 4 \mathrm{SE} \mathrm{P} 1+$ 9/4SE P2

Where $\mathrm{m}=$ mean, $\mathrm{a}=$ additive and $\mathrm{d}=$ dominance effects.

The significance of difference from three parameter model was estimated through t-test at the 0.05 and 0.01 levels of probability. In instances where the A, B, C and D values and test significantly deviated from zero in the joint scaling test of simple additive-dominance model, digenic interaction was assumed. The six parameter model of Hayman (1958), Mather and Jinks (1972) was used to estimate the variation present among generations by incorporating mean (m), additive effect (a), dominance effect (d) and the three digenic interaction components additive $\mathrm{x}$ additive (aa), dominance $\mathrm{x}$ dominance (dd) and additive $\mathrm{x}$ dominance (ad) as follows:

$\mathrm{m}=\mathrm{F} 2$;

$\mathrm{a}=\mathrm{BC} 1 \mathrm{P} 1-\mathrm{BC} 1 \mathrm{P} 2$;

$\mathrm{d}=-1 / 2 \mathrm{P} 1-1 / 2 \mathrm{P} 2+\mathrm{F} 1-4 \mathrm{~F} 2+2 \mathrm{BC} 1 \mathrm{P} 1+2 \mathrm{BC} 1 \mathrm{P} 2$;

$\mathrm{aa}=-4 \mathrm{~F} 2+2 \mathrm{BC} 1 \mathrm{P} 1+2 \mathrm{BC} 1 \mathrm{P} 2$;

$\mathrm{ad}=-1 / 2 \mathrm{P} 1+1 / 2 \mathrm{P} 2+\mathrm{BC} 1 \mathrm{P} 1-\mathrm{BC} 1 \mathrm{P} 2$;

$\mathrm{dd}=\mathrm{P} 1+\mathrm{P} 2+2 \mathrm{~F} 1+4 \mathrm{~F} 2-4 \mathrm{BC} 1 \mathrm{P} 1-4 \mathrm{BC} 1 \mathrm{P} 2$.

Genetic effect significance was tested using the same t-test for the ABC scaling test.

\section{Estimated number of genes contributing to thrips resistance:}

Number of genes controlling shattering was estimated based on formula developed by Bjarko and Line (1987). This formula was focused on the assumption that genes have equal effects in size and direction, no dominance, no epistasis and no linkage. The following formula was therefore applied:

$\mathrm{n}=(\mathrm{GR})^{2}[1.5-2 \mathrm{~h}(1-\mathrm{h}) / 8[(\mathrm{VF} 2)-(\mathrm{Vp} 1+\mathrm{Vp} 2+2 \mathrm{VF} 1) / 4)]$

Where, $n=$ the estimated number of genes.

$$
\mathrm{h}=\mathrm{F} 1-\frac{\left(P r-P_{s}\right)}{P S}
$$

$\mathrm{GR}=$ Genotypic range $(\mathrm{PS}-\mathrm{PR})$

$\mathrm{VF} 1, \mathrm{VF} 2, \mathrm{Vp} 1$ and $\mathrm{Vp} 2=$ Variances of $\mathrm{F} 1, \mathrm{~F} 2$, parent one and parent two respectively.

PS and PR = Susceptible parent and resistant parent respectively. 
Estimated broad and narrow sense heritability

For these parameters, following formulae were used:

$\left(\mathrm{h}^{2} \mathrm{~b}\right)=[\mathrm{VF} 2-(\mathrm{VP} 1+\mathrm{VP} 2+\mathrm{VF} 1) / 3] / \mathrm{VF} 2$

$\left(\mathrm{h}_{\mathrm{n}}^{2}\right)=[2 \mathrm{VF} 2-(\mathrm{VBC} 1 \mathrm{P} 1+\mathrm{VBC} 1 \mathrm{P} 2)] / \mathrm{VF} 2$

Where, $\mathrm{h}^{2}{ }_{\mathrm{b}}=$ broad sense heritability; $\mathrm{h}^{2}{ }_{\mathrm{n}}=$ narrow sense heritability, $\mathrm{V}=$ variance for $\mathrm{P} 1, \mathrm{P} 2, \mathrm{~F} 1, \mathrm{~F} 2, \mathrm{BC} 1 \mathrm{P} 1$ and $\mathrm{BC} 2 \mathrm{P} 2$ generations.

\section{Results et Discussion}

Results

Analysis of variance (ANOVA) revealed significant differences among the progenies (generations) indicating the presence of genetic variability based on parameters such as number of flowers abortion per plant, pods number per plant, thrips damage, thrips number per plant and 100 seed weight.

\section{Parents and progeny mean}

The mean values and their standard errors for the all analyzed characters are presented in Table 1. The resistant parent, Sanzi, compared to the susceptible parent Komcalle recorded the lowest mean for all the traits. It was ranged between 0.23 (number of flowers abortion per plant) and 8.36 (pods number per plant). Susceptible parent, Komcallé, scored mean varying from 0.70 (number of flowers abortion per plant) to 7.03 (pods number per plant). The traits such as thrips damage and thrips number per plant of generation $F_{1}$ were less than that of the susceptible parent, Komcallé, but close to the resistant parent (Sanzi). The resistant parent (Sanzi) had low values with means such as number of flowers abortion per plant (0.23) and number of thrips per plant (3.76) compared to that of susceptible parent, Komcallé, with respectively with 0.70 (flowers abortion per plant) and 7.03 (number pods per plant). For 100 seeds weight, Komcallé scored higher 100 seed weight (6.64) than Sanzi (6.58). The mid-parent values for all traits were greater than the values for the non-segregating population $(\mathrm{F} 1)$ and segregating populations (BC1P1, BC1P2 and $\mathrm{F} 2$ ). Values of dominance (D) were range between -1.410 and 2 . 
Table 1: Generation mean performances and degree of dominance based on parameters

\begin{tabular}{lccccc}
\hline & NFAP & NPP & $\begin{array}{c}\text { Thrips } \\
\text { damages }\end{array}$ & $\begin{array}{c}\text { Nbre } \\
\text { thrips/plt }\end{array}$ & $\begin{array}{c}100 \text { seeds } \\
\text { weight }\end{array}$ \\
\hline $\begin{array}{c}\text { P1 } \\
\text { Komcallé })\end{array}$ & 0.70 & 7.03 & 2.83 & 5.40 & 6.64 \\
\hline $\begin{array}{l}\text { P2 } \\
\text { Sanzi })\end{array}$ & 0.23 & 8.367 & 1.6 & 3.76 & 6.58 \\
\hline F1 & 0.33 & 5.46 & 1.63 & 1.76 & 10.6 \\
\hline BC1P1 & 0.12 & 3.45 & 1.12 & 1.41 & 10.08 \\
\hline BC1P2 & 0.39 & 6.88 & 2.041 & 4.13 & 9.84 \\
\hline F2 & 0.33 & 5.99 & 2.01 & 2.55 & 11.41 \\
\hline MP & 0.465 & 7.698 & 2.215 & 4.58 & 6.67 \\
\hline D & -0.06 & -1.119 & -0.292 & -1.410 & 2 \\
& $\begin{array}{c}\text { Dominance } \\
\text { incomplete }\end{array}$ & $\begin{array}{c}\text { Over } \\
\text { dominance }\end{array}$ & $\begin{array}{c}\text { Dominance } \\
\text { incomplete }\end{array}$ & $\begin{array}{c}\text { Dominance } \\
\text { incomplete }\end{array}$ & $\begin{array}{c}\text { Over } \\
\text { dominance }\end{array}$ \\
\hline S.E. & 0.082 & 0.531 & 0.166 & 0.474 & 0.112 \\
\hline
\end{tabular}

NB: NFAP: number of flowers abortion per plant, NPP: number of pods per plant, score: thrips damage, nbre thrips/plt: thrips number per plant, Pds100Gr: weight of 100 seeds. MP = Mid-parent; S.E = standard error of means, $\mathrm{D}=$ degree of dominance based on Falconer and Mackay (1996).

\section{The individual scaling}

Estimated gene effects for digenic epistasis interaction model or additive-dominance model and simple scaling test (A, B, C, D) for the evaluated traits from Komcallé $x$ Sanzi is presented in Table 2. The individual tests of epistasis A, B, C and D (Mather and Jinks, 1982) were calculated from population averages. The results of the A, B, C and D scales showed highly significant values and departure from zero. Tests A and B indicated aa, ad and $\mathrm{dd}$ as type of epistasis genes. On the other hand, the $\mathrm{C}$ test was indicative of the existence of type I epistasis. With test A, all the traits was significant but $\mathrm{B}$ was significant with some traits such as thrips damage, thrips number per plant, 100 seeds weight. As for test $\mathrm{C}$, it was significant with pods number per plant and thrips number per plant.

Table 2: Individual scaling test on progenies from crosses Komcallé $\times$ Sanzi

\begin{tabular}{lccccc}
\hline \multicolumn{5}{c}{ Individual scaling } \\
\hline $\begin{array}{l}\text { Scaling } \\
\text { test }\end{array}$ & NFAP & NPP & Thrips damage & $\begin{array}{c}\text { Thrips } \\
\text { number/Plant }\end{array}$ & $\begin{array}{c}100 \text { seeds } \\
\text { weight }\end{array}$ \\
\hline $\mathbf{A}$ & $-0.79^{* * *}$ & $-5.59^{* * *}$ & $-2.22^{* * *}$ & $-4.34^{* * *}$ & $2.92^{* * *}$ \\
\hline B & $0.22^{*}$ & -0.067 & $0.852^{* * *}$ & $2.74^{* * *}$ & $2.5^{* * *}$ \\
\hline C & $-0.27^{*}$ & $-2.357^{* * *}$ & $0.35^{*}$ & $-2.48^{* *}$ & $11.22^{* * *}$ \\
\hline D & $0.15^{*}$ & $1.65^{*}$ & $0.859^{*}$ & $-0.44^{*}$ & $2.9^{*}$ \\
\hline
\end{tabular}

NB: * signicant different from Zero; $* * *$ significant at $5 \%$ and $1 \%$ probability; NFAP: number of flowers abortion per plant; NPP: number of pods per plant; score: thrips damage; nbre thrips/plt: thrips number per plant, Pds100Gr: 100 seeds weight. 
Since there was inadequacy with three parameter model, the six parameter model was exploited to estimate mode of gene action for thrips resistance in cowpea (Table 3). Gene effects were estimated using unweighted least square mean method (Hayman, 1958). Additive (a) gene effect was negative (towards the susceptible parent) for all the traits and positive for 100 seeds weight. Elsewhere, additive (a) gene effect was significant for thrips damage, thrips number per plant and 100 seeds weight and was range from -3.43 to 0.24 . The dominance (d), additive $x$ additive (aa) and additive $\mathrm{x}$ dominance (ad) effects were negative (towards the resistant parent) from the traits number of flowers abortion per plant, thrips damage and positive for the traits 100 seeds weight. They were range respectably from -0.70 to $4.77 ;-3.3$ to 0.88 and -5.505 to 0.21 . Dominance $\mathrm{x}$ dominance effect was positive (towards the resistant parent) for all traits and was significant from number pods per plant and number of flowers abortion per plant ranged from 0.38 to 8.957 .

Table 3: Estimation of gene effects involved in flower bud thrips resistant to cowpea

\section{Epistasis effects estimated from six parameter model}

\begin{tabular}{|c|c|c|c|c|c|}
\hline \multicolumn{6}{|c|}{ Traits } \\
\hline $\begin{array}{l}\text { Scaling test } \\
\text { and } \\
\text { parameter }\end{array}$ & NFAP & NPP & $\begin{array}{c}\text { Thrips } \\
\text { damage }\end{array}$ & $\begin{array}{c}\text { Thrips } \\
\text { number/Plant }\end{array}$ & $\begin{array}{c}100 \text { seeds } \\
\text { weight }\end{array}$ \\
\hline $\mathbf{m}$ & $\begin{array}{c}0.33 \\
\pm 0.574^{* * * *} \\
\end{array}$ & $\begin{array}{c}5.99 \\
\pm 2.447^{* * * *}\end{array}$ & $\begin{array}{c}2.01 \\
\pm 1,417^{\text {**** }}\end{array}$ & $\begin{array}{c}2.55 \\
\pm 1,596^{* * *}\end{array}$ & $\begin{array}{c}11.41 \\
\pm 3,337^{\text {**** }}\end{array}$ \\
\hline $\mathbf{a}$ & -0.7 & -3.43 & $-0.921^{* * *}$ & $-2.72^{\text {**** }}$ & $0.24^{* * * *}$ \\
\hline d & -0.205 & 2.828 & -0.703 & 1.82 & $4.77^{* * * *}$ \\
\hline aa & -0.3 & -3.3 & -1.718 & 0.88 & $-5.8^{* * *}$ \\
\hline ad & -5.505 & -2.761 & -1.536 & -3.54 & 0.21 \\
\hline dd & $0.87^{* * * *}$ & $8.957^{* * *}$ & 3.086 & 0.72 & 0.38 \\
\hline Gene action & $\mathrm{D}$ & $\mathrm{C}$ & $\mathrm{D}$ & $\mathrm{C}$ & $\mathrm{C}$ \\
\hline
\end{tabular}

NB: $[\mathrm{m}]=$ mean; [a ]= additive effects; [d ]= dominance effects; [aa] = additivex additive; $[\mathrm{ad}]=$ additive $\times$ dominance effect; $[\mathrm{dd}]=$ dominance $\times$ dominance effects; $* * *$ significant at $5 \%$ and $1 \%$ probability; NFAP: number of flowers abortion; NPP: number of pods per plant; score: thrips damage; and nbre thrips/plt: thrips number per plant; $\mathrm{D}=$ duplicate; $\mathrm{C}$ : complementary.

\section{Estimated number of genes controlling thrips resistance}

The results of estimating number of genes for thrips resistance are shown in the Table 4 . The number of factors was ranged from 3 to 6 with 4 as the effective factors involved for thrips damage and the number of thrips per plant. Number of genes controlling thrips resistance 3 for yield parameters such as number of aborted flowers per plant and pods number per plant, whereas it was 6 for 100 seeds weight. 
Table 4: the number of the factors

\begin{tabular}{lcc}
\hline Parameters & Number of progenies & Number of genes \\
\hline NFAP & 120 & 3 \\
\hline NPP & 120 & 3 \\
\hline Thrips damage & 120 & 4 \\
Thrips number/plant & 120 & 4 \\
\hline 100 seeds weight & 120 & 6 \\
\hline
\end{tabular}

\section{Heritability derive from the cross Komcallé $\times$ Sanzi}

The estimate of heritability for thrips resistance is presented in Table 5. Heritability in the broad sense for thrips damage parameters and number of thrips per plant was 0,12 and 0.016, respectively. As far as heritability in the narrow sense is concerned, it was estimated to 0.11 for the damage of thrips and 0.01 for the number of thrips per plant.

Table 5: Heritability based on thrips damage and thrips number per plant.

\begin{tabular}{lcc}
\hline Parameters & $\mathbf{h}^{2}{ }_{\mathbf{b}}$ & $\mathbf{h}^{2}{ }_{\mathbf{n}}$ \\
\hline Thrips damage & 0,12 & 0,11 \\
\cline { 2 - 3 } Thrips number/plant & 0,016 & 0,01 \\
\hline
\end{tabular}

\section{Discussion}

Variability was obeserved between generation based on studys' parameters meaning that contrasting parents were used to develop progenies. Information about the genetic components variation helps breeder to select desirable parents for crossing programs and also to decide suitable breeding procedure for the genetic improvement of various quantitative traits (Singh and Narayanan, 1993; Meena et al., 2015).

The generation means analysis indicated that the additive-dominance model was not adequate to explain the gene action involved in the inheritance of thrips resistance into cowpea. This result was in agreement with the findings from Omo-Ikerodah et al. (2009) in genetic analysis of flowers bud thrips (Megalurothrips sjostedti) resistance to cowpea (Vigna unguiculata [L.] Walp.).

Duplicate gene effects were recorded with number of flowers abortion and thrips damage per plant. Dominance $(d)$ and dominance $\times$ dominance $(\mathrm{dd})$ gene effects displayed opposite sign interactions for these traits suggesting that breeders should delay selection to allow high-potential recombinants during hybridization. The values of dominance (d) and dominance $\times$ dominance (dd) interaction were in the same direction with parameters pods number per plant, thrips number per plant and 100 seeds weight showing complementary gene actions. This indicates selected parents for crossing are divergent based on traits. P2 (Sanzi), F1 and BC1P2 scored low thrips damages indicating the dominance expressed from resistance gene effects. 
Positive or negative form of additive $\times$ additive [aa] interaction showed association and dispersion of alleles in parents.

Estimated degree of dominance from mean genotypic values of traits support the hypothesis of environmental factors influencing genes controlling the traits considered in this study. Results showed that there was incomplete dominance $(-1<\mathrm{D}<0$ or $0<\mathrm{D}<1)$ and over dominance $(\mathrm{D}<-1$ or $\mathrm{D}>1)$ types of gene effects since both positive and negative signs of dominance were found. This was in agreement with the findings from Lagervall (1960) study reporting that negative or positive degree of dominance is common in inbred lines. Further, the same author indicated that epistasis may bias the estimate of dominance to a larger or lesser extent Lagervall (1961). It is also in agreement with the results from Gonné et al. (2018) study with progenies generated from VYA $\times$ SANZI. Dominance $(d)$ and dominance $\times$ dominance (dd) gene effects displayed opposite signs with traits number of flower abortions, pods number per plant and thrips number per plant indicating duplicate epistasis. The values of dominance (d) and dominance $\times$ dominance (dd) interactions were in the same direction for traits such as thrips damage and 100 seeds weight. Presence of complementary gene action for above traits indicated two contrasting parents used for crossing. The classification of gene interaction depends on the magnitude and sign of the estimates of dominance (d) and dominance $\times$ dominance (dd) effects when there are many pairs of interacting genes. The sign associated with the estimates of additive effects (a) and dominance effects (d) indicated the parent having dominant gene or positive alleles for increasing the resistance of traits. Therefore, the positive additive [a] for 100 seeds weight indicated the predominant of additive gene effect and selection for this trait can be done by early stage. The negative value of additive [a] for traits number of flower abortions, pods number per plant, thrips damage and number of thrips per plant indicated that the inheritance of these traits is not controlled by additive gene action. Presence of dominance [d] gene action indicated that selection should be delayed until heterozygosity will be reduced within population. The earlier findings reported that traits with high magnitude of dominance than additive can be improved through conventional breeding approach such as pedigree, bulk or single seed descent method in case of delaying selection until later generation when the dominance effect would have diminished (Khattak et al., 2004). In the contrast, the significant but negative values of dominance [d], additive $\mathrm{x}$ additive [aa], additive $\mathrm{x}$ dominance $[\mathrm{ad}]$ and dominance $\mathrm{x}$ dominance $[\mathrm{dd}]$ for some traits showed that negative alleles were also dispersed in the parents involved in the cross. Negative sign of domiancne [d] in cross for any trait explained that dominance effects were contributed by the parents having alleles responsible for low value for the traits. 
The minimum number of effective factors (genes) controlling the inheritance of flower bud thrips resistance in cowpea varied from 3 to 6 depending on the trait, suggesting the presence of polygenic group for the traits measured. The results confirmed that effective progress could be made for all of the traits considered in this study through selection at late generations. This is in agreement with the findings from Asare (2012), Doumbia and Gonné et al. (2018) studies on the genetic analysis of cowpea resistance to flowers bud thrips (Megalurothrips sjostedti) with 3.4 (number of peduncle per plant) to 6.17 (total number of pods per plant) and their inheritance varied from 3 to 5 .

Broad and narrow sense heritabilities estimated for flower bud thrips resistance were low indicating large effect of environmental effects on the traits. This is in agreement with the findings from Asare (2012) and Gonné et al. (2018). However, Omo-Ikerodah et al. (2009) and Doumbia et al. (2016) found high broad sense heritability for flower bud thrips resistance. According to Acquaah (2007) and Asare (2012), the action of minor genes is small and significantly influenced by the environment. The low heritability observed can therefore be attributed to the action of minor genes on the expression of the trait.

\section{Conclusion}

The effects of genes such as complementarity and duplication have been noted in the control of resistance for different parameters. The polygenic character for thrip resistance has been confirmed through the calculation of the number of genes involved in this source of resistance. This gene number varied from 3 to 6 for the different parameters estimated. As for the heredity mode for resistance to thrips in cowpea, dominance and epistasis contributed enormously.

\section{References:}

1. Acquaah, G. (2007). Introduction to quantitative genetics. In: Principles of plant genetics and breeding. (pp 121-145).

2. Agbahoungba, S., Karungi, J., Odong, T. L., Badji, A., Kumi, F., Mwila, N. and Rubaihayo, P. R. (2018). Biochemical constituents influencing the resistance to flower bud thrips in cowpea [Vigna unguiculata (1.) walp] germplasm. The Journal of Animal \& Plant Sciences, vol.28, ${ }^{\circ} 1 .(128-137)$ ISSN: 1018-70

3. Asare, K. B.(2012). Inheritance of resistance to flower bud thrips (Megalurothrips sjostedti) in cowpea. Thesis university of Ghana. (pp80). 
4. Bjarko, M. E. and Line, R. F. (1987). Heritability and number of genes controlling rust resistance in four cultivars of wheat. Phytopathology 78(457-461).

5. Cavalli, L. L. (1952). An analysis of linkage in quantitative genetics. In: C. R. Rieve and C. H. Waddington (eds.). Quantitative Inheritance, (pp. 135- 144). HSMO, London.

6. Dormatey, R., Atokple, I. D. K., \& Ishiyaku, M. F. (2015). Genetics of thrips resistance in cowpea. International Journal of Research in Agricultural Sciences, 2, (2348-3997).

7. Doumbia I. Z.(2016). Genetic improvement of cowpea for resistance to thrips (Megalurthrips sjostedti) in Mali. Thesis university of Ghana.

8. Doumbia, I. Z., Boukar, O., Touré, M., Tamò, M., Tignegre, J. B. D. L. S., Fatokun, C., Togola, A., Tongoona, P. and Ayertey, J. N. (2019). Evaluation of cowpea accessions for resistance to flower bud thrips (Megalurothrips sjostedti) in Mali: Journal of Genetics, Genomics \& Plant Breeding 3(2) 15-30 : ISSN (Online): 2581-3293.

9. Falconer, D.S. and Mackay, T.F.C. (1996). Introduction to quantitative genetics, 4 edn. Essex, UK: Longman.

10. Gonné, S., Fonji, M. A., Boukar, O., Fatokun, C., Tongoona, P. B. Ayertey, J., and Offei, S. K. (2018). Generation Mean Analysis in Cowpea [Vigna unguiculata (L.) Walp.] under Flower Thrips infestation. Journal of Agricultural Science; Vol. 10, No. 4; 2018 ISSN 1916-9752 E-ISSN (1916-9760).

11. Hayman, B. I. (1955). The description and analysis of gene action and interaction. Cold Spring Harbor Symposia on Quantitative Biology, 20(79-86).

12. Hayman, B. P. (1958). The separation of epitasis from additive and dominance variation in generation means. Heredity, 12(371-380). doi:10.1038/hdy.1958.36

13. Jackai, L. E. N., and Singh, S. R. (1988). Screening techniques for host plant resistance to cowpea insect pests. Tropical Grain Legum Bull 35 (2-18).

14. Jinks J.I and Jones M. R.,(1958)..Estimation of components of Heterosis. Genetics March 1,1958 vol. 43 no. 2 (223-234).

15. Kang, M. S. (1994) Applied quantitative genetics. 2477 Creekside Drive Baton Rouge, Louisiana, USA, (pp 79-81).

16. Khattak, G. S. S., Ashraf, M. and Khan, M. S. (2004). Assessment of Genetic Variation for Yield and Yield Component in Mung Bean [Vigna Radiate (L.) Wilczek] Using Generation Mean Analysis. Pak. J. Bot., 36(3): (583-588). 
17. Lagervall, P. M. (1960). Quantitative inheritance and dominance I. The coefficient of relationship caused by dominance. Hereditas, 46, (481-496). https://doi.org/10.1111/j.1601-5223.1960.tb03095.

18. Lagervall, P. M. (1961). Quantitative inheritance and dominance II. The genic and the dominance variance under inbreeding. Hereditas, 47, (111-130).

19. Mather, K. (1949). Biometrical Genetics in the Study of Continuous Variation. Methun and Company Limited, London.

20. Mather, K. and Jinks, J. L. (1972). Biometrical genetics. Heredity, 29 (AUG), 101.

21. Mather, K. and Jinks, J. L. (1982). Biometrical Genetics. The study of continuous variation. Longman London (pp 396).

22. Meena O. P. and Bahadur V.,2015. Breeding potential of indeterminate tomato (solanum lycopersicum l.) accessions using $\mathrm{d}^{2}$ analysis. SABRAO Journal of Breeding and Genetics vol. 47 n¹( 49-59).

23. Ngakou, A., Tamo, M., Parah, I. A., Nwaga, D., Ntonifor, N. N., Korie, S. and Nebane, C. L. N. (2008). Management of cowpea flower thrips, Megalurothrips sjostedti (Thysanoptera: Thripidore) in Cameroon. Crop Protection (274, 481-488). https//doi.org/10.1016/j.cropro.2007.08.002

24. Omo-Ikerodah, E. E., Fatokun, C. A. and Fawole, I. (2009). Genetics analysis of resistance to flower bud thrips (Megalurothrips sjostedti) in cowpea (Vigna unguiculata (L.) Walp.). Euphytica (165: 143-154).

25. Prabhu, S. M., Meenakshi, G. N., Jeyaprakash, P., Selvakumar, R. and Prabhakaran, N. K. (2017). Generation Mean Analysis for Yield and Its Contributing Characters in F2 Populations of Rice (Oryza sativa L.). Int. J. Pure App. Biosci. ( 373-380 )

26. Sidibé, H., Batiéno, B. J., Tignigré, J. B. D. L. S., Kusi, F., Ouédraogo, T. J. and Sawadogo, M. (2018). Screening Twenty Cowpea (Vigna unguiculata (L.) Walp) Genotypes for Resistance to Thrips (Megalurothrips sjöstedti) in Burkina Faso. Journal of Agricultural Studies (ISSN 2166-0379 2018, Vol. 6, No. 4).

27. Singh, P. \& Narayanan, S.S. (1993). Biometrical Techniques in Plant Breeding (1 ed.), Kalyani Publishers, New Delhi, India, (p.182).

28. Singh, S. R. and Allen, D. J. (1980). Pests, diseases, resistance and protection in cowpea. In R. J. Summerfield and A. H. Bunting (eds) Advances in Legume Science (London: Her Majesty's Stationary Office), (pp. 419-443). 